\title{
Synthesis, characterization, anticancer activity and biological activities of vanadium complexes of 2-mercapto-5-methyl-benzimidazole as sulphur donor ligand
}

\begin{abstract}
Vanadium complexes have been synthesized by the reaction of 2-mercapto-5-methylbenzimidazole with carbon disulphide and then with different vanadium salts in different $\mathrm{M} / \mathrm{L}$ ratio. The synthesized vanadium complexes have been characterized by elemental microanalysis $(\mathrm{CHN})$, FT-IR spectroscopy and NMR $\left({ }^{1} \mathrm{H},{ }^{13} \mathrm{C}\right)$ spectroscopy. Elemental analysis data shows good agreement between found and calculated values. FT-IR spectroscopic data suggests the bidentate nature of the ligand. The results of multinuclear NMR revealed that coordination occurs through $\mathrm{NCS}_{2}$ moiety. Antibacterial activity data showed that ligand and complexes showed moderate antibacterial and anti-biofilm activity. The cytotoxicity studies showed that vanadium complex (3) is less cytotoxic $(2.27 \%)$ and complex (1) has maximum cytotoxicity $(11.04 \%)$. In vitro oxidative DNA damage protection assay showed that synthesized vanadium complexes exhibited plasmid DNA protection by scavenging the oxidation products. Results of in vitro anticancer activity showed that oxoperoxo vanadium complex (2) exhibited significant anticancer activity $\left(\mathrm{IC}_{50} 2.55 \mu \mathrm{M}\right)$ against $\mathrm{H} 460 \mathrm{MX} 2$ cell line.
\end{abstract}

Keywords: vanadium complexes, synthesis, characterization, anticancer activity, biological activities
Volume 9 Issue 2 - 2020

\section{Mudassir Jabeen,' Saqib Ali, ${ }^{2}$ Saira Shahzadi, ${ }^{2}$ \\ Liwu Fu, ${ }^{3}$ Muhammad Shahid, ${ }^{4}$ Matloob Ahmad'}

'Department of Chemistry, GC University, Faisalabad, Pakistan 2Department of Chemistry, Quaid-i-Azam University, Islamabad, Pakistan

${ }^{3}$ State key laboratory of Oncology in South China, cancer center, Sun Yat-Sen University, Guangzhou, China

${ }^{4}$ Department of Chemistry and Biochemistry, Agriculture University, Faisalabad, Pakistan

Correspondence: Saira Shahzadi, Department of Chemistry, Quaid-i-Azam University, 45320-Islamabad, Pakistan, Emaildrsa54@hotmail.com, sairashahzadi@hotmail.com

Received: February 12, 2020 | Published: March 16, 2020

\section{Introduction}

The significance of metal ions is well established in the biological system. The most important feature of metal-coordinated system is the spatial arrangement of ligands around the central metal ion. ${ }^{1-3}$ Among different transition metal ions which are used for various pharmacological activities, vanadium complexes are reported to exhibit various biological activities including antimicrobial, antitumor, anti hyperlipidemic, anti obesity, anti hypertension, insulin-enhancing effect, improvement of oxygen carrying efficiency of hemoglobin and myoglobin and so on. ${ }^{4-6}$ Vanadium complexes are also used for lowering of blood glucose level, ${ }^{7-10}$ natriuretic and diuretic effects. For the development of vanado drugs, much work has been done for vanadyl ion coordinated to various organic ligands which show insulinmimetic effects. ${ }^{11-13}$ Vanadium complexes exert preventive action against chemical carcinogenesis by the arrest of cell-cycle through the process of DNA fragmentation and cleavage. ${ }^{14}$ Vanadium penetrates to the cells in the form of vanadate $\mathrm{VO}^{-3}$ which is then reduced to $\mathrm{VO}^{2+}$ (vanadyl)ion at physiological $\mathrm{pH} \cdot{ }^{15-17}$ Such ions combine with different bio molecules such as nucleic acids, proteins, phospholipids, phosphates and alter the structural properties of these molecules. ${ }^{18,19}$ The effect of vanadium complexes on pulmonary inflammation and chemokine mRNA expression have been investigated. ${ }^{20}$ Vanadate ion induces the activation of a protein tyrosine kinase and also on the biological action of insulin. The inhibitory action of vanadyl ions on $\mathrm{Na}^{-}$and K-ATPase activity has also been investigated. ${ }^{16,21,22}$ Marine biofouling which is the colonization of marine microorganisms on ship's hulls is a problem that does not have any environmentally- compatible solution. Marine biofouling leads to more hydrodynamic drag that causes increased consumption of fuel and emissions of greenhouse gases. ${ }^{23}$ Vanadium compounds inhibit the marine biofouling. These compounds exert significant antibacterial effect that prevents biofouling without being harmful to marine biota. Vanadium compounds can be used as an alternative to conventionally used antifouling agents. ${ }^{24}$ In continuation of our previous research work, ${ }^{25-}$ ${ }^{29}$ here we report the synthesis of three new vanadium complexes which have been characterized by elemental microanalysis (CHN), NMR and FTIR spectroscopy. These complexes were also checked for various biological activities.

\section{Materials and methods}

All chemicals used for experimental work were of analytical grade and used without any further purification. Vanadyl sulphate trihydrate $\left(\mathrm{VOSO}_{4} \cdot 3 \mathrm{H}_{2} \mathrm{O}\right)$, vanadium (III) chloride $\left(\mathrm{VCl}_{3}\right)$ and 2-mercapto-5-methyl-benzimidazole were purchased from Aldrich Chemical Company (USA). Ammonium-meta-vanadate $\left(\mathrm{NH}_{4} \mathrm{VO}_{3}\right)$ was purchased from BDH (England). All organic solvents (methanol, ethanol, chloroform, acetone, DMSO etc.) were of analytical grade and purchased from Merck (Germany).

Melting points of all compounds were checked using electro thermal melting point apparatus, MP-D Mitamura Rieken Kogyo (Japan) and are found uncorrected. Elemental microanalysis was performed using CHNS-932 analyzer Leco (USA). FTIR spectra were recorded as $\mathrm{KBr} / \mathrm{CsBr}$ pellets using a Perkin Elmer FT-IR-1000 spectrophotometer in the range 4000-250 $\mathrm{cm}^{-1}$. 


\section{A. General procedure for the synthesis of vanadium complexes}

Dissolved 2-mercapto-5-methyl-benzimidazole $(1 \mathrm{mmol})$ in $30 \mathrm{~mL}$ of absolute methanol in a round bottom flask $(250 \mathrm{~mL})$ with continuous stirring, then $\mathrm{CS}_{2}$ (1 $1 \mathrm{mmol}$ ) was added drop wise in the above solution and reaction mixture was stirred at room temperature for about half an hour; then added methanolic solution of $\mathrm{VOSO}_{4} \cdot 3 \mathrm{H}_{2} \mathrm{O}(1) / \mathrm{NH}_{4} \mathrm{VO}_{3}$ and $\mathrm{H}_{2} \mathrm{O}_{2}$ solution (2) $/ \mathrm{VCl}_{3}(3)$ in $1: 2 \mathrm{M} / \mathrm{L}$ ratio. The reaction mixture was stirred for about $6 \mathrm{~h}$ at room temperature. The solvent was evaporated through rotary evaporator and solid product obtained was dried in air (Scheme 1).<smiles>Cc1ccc2c(c1)nc(S)n2C(=S)S</smiles>

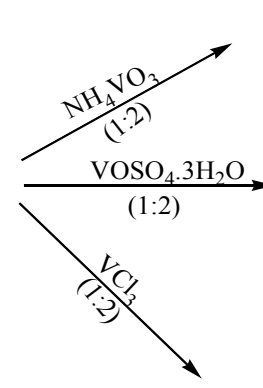

$\mathrm{H}_{3} \mathrm{C}$<smiles></smiles><smiles>O=S123SC(SC(n4c(S)nc5ccccc54)=[SH]1)(S2)S3</smiles>

$\mathrm{H}_{3} \mathrm{C}^{2}$

(1)<smiles>Cc1ccc2c(c1)nc(S)n2C1=S2(Cl)(SC(n3c(S)nc4ccccc43)=[SH]2)S1</smiles>

Scheme I Synthesis of vanadium complexes from 2-mercapto-5-methyl-benzimidazole.

\section{B. Antibacterial activity}

3,2-mercapto-5-methyl-benzimidazole and its vanadium complexes (1)-(3) were screened for in vitro antibacterial activity against two bacteria as Bacillus subtilis and Escherichia coli by disc diffusion method. ${ }^{30}$ Cultures were grown by using nutrient agar as a medium in Petri plates and slants. For the preparation of inoculums $13 \mathrm{~g} / \mathrm{L}$ of nutrient broth was mixed well with distilled water and autoclaved. Added pure culture $(10 \mu \mathrm{L})$ of bacterial strain in growth medium stirred well and then kept in an orbital shaker at $37^{\circ} \mathrm{C}$ for about $24 \mathrm{~h}$. The inoculums were stored in a refrigerator at about $4^{\circ} \mathrm{C}$ temperature. The preserved inoculums $\left(1 \times 10^{8}\right.$ spores $\left./ \mathrm{mL}\right)$ were further used for analysis. Nutrient agar $(28 \mathrm{~g} / \mathrm{L})$ was mixed well in distilled water and homogenously distributed. Sterilized the growth medium by using an autoclave for about 15 minutes at $121^{\circ} \mathrm{C}$ temperature; inoculums $(100 \mu \mathrm{L} / 100 \mathrm{~mL})$ were then shifted to growth medium and poured in sterilized petri plates. Discs of filter paper were made and laid flat on growth medium containing $100 \mu \mathrm{L}$ of tested sample; incubated the Petri plates at about $37^{\circ} \mathrm{C}$ temperature for 24 hours in order to multiply bacteria. The compounds having good antibacterial activity stopped the growth of bacteria and clear zones are visualized. Zone reader is used to measure the inhibition zone. ${ }^{31}$

\section{Cytotoxicity by hemolytic activity}

Cytotoxicity of the compounds was checked by hemolytic activity using the standard Powell's method, ${ }^{32}$ freshly taken heparinized $3 \mathrm{~mL}$ human blood was smoothly mixed and poured to a sterilized falcon tube $(15 \mathrm{~mL})$ and centrifuged for 5 minutes at $4,200 \mathrm{rpm}$. The supernatant was poured off and formed viscous pellet was washed three times with chilled $\left(4^{\circ} \mathrm{C}\right)(5 \mathrm{~mL})$ sterile isotonic PBS (phosphate-buffered saline) solution, adjusted the system to $\mathrm{pH}$ 7.4. Mix the solution for half hour at $25-30^{\circ} \mathrm{C}$ temperature; then suspended the washed cells in $20 \mathrm{~mL}$ of chilled phosphate buffer saline. The blood cell suspension was maintained on wet ice and diluted with sterile PBS, the cell count should be $7.068 \times 10^{8}$ cells per $\mathrm{mL}$ for each test. The sample $(20 \mu \mathrm{L})$ in five different solvents was taken in $2 \mathrm{~mL}$ eppendorf tubes. For each assay Triton X-100 (0.1\%) was taken as control (positive) for $100 \%$ blood lysis and PBS was taken as a negative control ( $0 \%$ lysis). In each eppendorf tube that contained $20 \mu \mathrm{L}$ of sample, $180 \mu \mathrm{L}$ of blood cell suspension was added and mixed thoroughly with a pipette tip. The tubes were then incubated for $37^{\circ} \mathrm{C}$ for 35 minutes and agitated for 10 minutes after the incubation. The eppendorf tubes were placed on ice for about 5 minutes and then centrifuged at 4,200rpm. About $100 \mu \mathrm{L}$ of supernatant was taken from supernatant and diluted with $900 \mu \mathrm{L}$ cold PBS. All tubes were maintained on wet ice after dilution. Then poured $200 \mu \mathrm{L}$ into 96 well plates and three replicates were taken which contain one positive control and one negative control. After this, absorbance at $576 \mathrm{~nm}$ was taken at BioTek, $\mu$ CuantTM instrument (BioTek, Winooski, VT, USA). Triton X-100 (0.1\%) was used as positive control (100\% of blood lysis) and PBS buffer as negative control ( $0 \%$ of blood lysis). The experiment was done in triplicate. The $\%$ hemolysis values were obtained using the following formula:

$$
\% \text { Hemolysis }=H b_{A B S} / H b_{100 \% A B S} \times 100
$$




\section{Biofilm inhibition assay}

Those bacteria that possess good adhesion property to the surfaces can produce the biofilm. For determination of microbial adhesion to the surfaces in the presence of the vanadium complexes, the micro titre plates were prepared as previously described. ${ }^{33}$ Briefly, a bacterial culture and yeast were grown overnight in the broth media. Then, the cultures were diluted upto 1:100 into fresh medium for biofilm inhibition assay. The diluted solution $(200 \mu \mathrm{L})$ was added to $96-$ well plate. After the growth phase, the medium was removed carefully with pipette, the wells present in micro titre plates were rinsed three times with $200 \mu \mathrm{L}$ of sterile PBS. After washing, wells were filled with $96 \%$ ethanol for 15 minutes. The micro titre plates were dried in air and then, $200 \mu \mathrm{L}$ of $1 \%$ crystal violet were added for 5 minutes. Then, the micro titre plates were washed with distilled water, and then dried. Finally, $200 \mu \mathrm{L}$ of $33 \%$ glacial acetic acid were added to the wells and absorbance was measured at 540nm with an ELISA reader. Data for biofilm formation of all strains were compared with the data obtained for the negative control. S. aureus PTCC 1431 was used as positive control and microbial medium without microorganisms was used as the negative control.

\section{E. In vitro anticancer activity}

The in vitro anticancer activity of the synthesized vanadium complexes against different cancer cell lines was performed by MTT assay according to Mosmann's method.$^{34}$ In MTT assay, the reduction of soluble 3-(4,5-dimethyl-2-thiazolyl)-2,5-diphenyl-2H-tetrazolium bromide (MTT) occurs into a blue-purple Formosan product that is mainly formed by the mitochondrial reductase activity within living cells. The cells used for this assay were cultured in RPMI 1640 medium which is supplemented with fetal calf serum (10\%). Cells were suspended in growth medium $\left(2 \times 10^{4}\right.$ cells $\left./ \mathrm{mL}\right)$ were poured in 96-well plates and incubated at about $37^{\circ} \mathrm{C}$ in a $\mathrm{CO}_{2}(5 \%)$ incubator. After 12 hours, $2 \mathrm{~mL}$ of test sample was added to cells in 96-well plates and cultured at $37^{\circ} \mathrm{C}$ for 3 days. The cells were mixed with MTT solution $(20 \mu \mathrm{L})$ and then incubated for about $4 \mathrm{~h}$ at $37^{\circ} \mathrm{C}$. The supernatant was removed from each well and DMSO $(100 \mathrm{~mL})$ was added to each well in order to dissolve the Formosan crystals that were formed by the reduction of MTT. After mixing with mechanical plate mixer, the absorbance of each well was measured by a micro plate reader using a test wavelength of $570 \mathrm{~nm}$. The results were expressed in $\mathrm{IC}_{50}$ values which is concentration of drugs inducing $50 \%$ inhibition of cell growth of treated cells when compared to the growth of control cells. Each experiment was performed in triplicate. There was a good reproducibility between replicate wells with standard errors below 10 $\%$.

\section{Results}

The ligand and vanadium complexes are solids and stable at room temperature. Physical data is summarized in Table 1.

\section{a. FTIR spectroscopy}

FT-IR spectra were recorded as $\mathrm{KBr} / \mathrm{CsBr}$ discs, in the range $4000-250 \mathrm{~cm}^{-1}$ (Table 2). The vanadium complexes (1)-(3) showed complexation through sulphur atom of - $\mathrm{NCS}_{2}$ moiety.

\section{b. ${ }^{1} \mathrm{H}-\mathrm{NMR}$ spectroscopy}

The characteristic signals in the ${ }^{1} \mathrm{H}$ NMR spectra were recorded in duterated DMSO and data is given in Table 3 while NMR numbering scheme is given in Scheme 2.

Table I Physical data of vanadium complexes of 2-mercapto-5-methyl-benzimidazole

\begin{tabular}{llllllll}
\hline Comp No. & Mol formula & Mol.Wt & Melting point & Yield (\%) & \%C (found) & \%H (found) & \%N (found) \\
\hline $\mathrm{HL}$ & $\mathrm{C}_{8} \mathrm{H}_{8} \mathrm{~N}_{2} \mathrm{~S}$ & 164.23 & $290-293$ & - & $58.5(58.56)$ & $4.91(4.95)$ & $17.05(17.02)$ \\
$\mathrm{I}$ & {$\left[\mathrm{VO}\left(\mathrm{C}_{9} \mathrm{H}_{7} \mathrm{~N}_{2} \mathrm{~S}_{3}\right)_{2}\right]^{\mathrm{V}}$} & 545.65 & $202 \mathrm{Dec}$ & 65.43 & $39.62(39.58)$ & $2.59(2.54)$ & $10.26(10.3)$ \\
2 & {$\left[\mathrm{VO}\left(\mathrm{O}_{2}\right)\left(\mathrm{C}_{9} \mathrm{H}_{7} \mathrm{~N}_{2} \mathrm{~S}_{3}\right)_{2}\right]^{\vee}$} & 577.65 & $149 \mathrm{Dec}$ & 56.12 & $37.42(37.48)$ & $2.44(2.48)$ & $9.69(9.72)$ \\
3 & {$\left[\mathrm{VCl}\left(\mathrm{C}_{9} \mathrm{H}_{7} \mathrm{~N}_{2} \mathrm{~S}_{3}\right)_{2}\right]^{\mathrm{V}}$} & 565.15 & $186 \mathrm{Dec}$ & 58.70 & $38.25(38.27)$ & $2.50(2.48)$ & $9.90(9.92)$ \\
\hline
\end{tabular}

Table 2 IR spectral data ${ }^{a}\left(\mathrm{~cm}^{-1}\right)$ of vanadium complexes of 2-mercapto-5-methyl-benzimidazole

\begin{tabular}{llllll}
\hline Comp No. & $v(V=O)$ & $v(V-S)$ & $v(C S S)$ & $v(V-C l)$ & $v(C-N)$ \\
\hline 1 & $966 s$ & $439 m$ & $1182 \mathrm{~s}$ & - & $1368 \mathrm{~s}$ \\
2 & $958 \mathrm{~s}$ & $504 \mathrm{~m}$ & $1170 \mathrm{~m}$ & - & $1371 \mathrm{~s}$ \\
3 & - & $438 \mathrm{w}$ & $1169 \mathrm{~m}$ & $400 \mathrm{~m}$ & $1370 \mathrm{~s}$ \\
\hline
\end{tabular}

s-strong; m-medium; w-weak

Table 3 'H-NMR spectral data ${ }^{\mathrm{a}, \mathrm{b}}$ (Ppm) of ligand and its vanadium complexes

Chemical Shift (ppm)

\begin{tabular}{lllll}
\hline \multicolumn{5}{l}{ Chemical Shift (ppm) } \\
\cline { 2 - 5 } Proton No. & $\mathbf{( H L )}$ & $\mathbf{I}$ & $\mathbf{2}$ & 3 \\
\hline 2 & $7.39-7.45 \mathrm{~d}(6.3)$ & $7.34-7.42 \mathrm{~d}(6.4)$ & $7.65-7.73 \mathrm{~d}(6.3)$ & $7.54-7.67 \mathrm{~d}(6.3)$ \\
3 & $7.05-7.16 \mathrm{~d}(6.4)$ & $7.09-7.20 \mathrm{~d}(6.5)$ & $7.11-7.18 \mathrm{~d}(6.3)$ & $7.23-7.28 \mathrm{~d}(6.4)$ \\
\hline
\end{tabular}


Table continue

\begin{tabular}{lllll}
\hline \multicolumn{5}{c}{ Chemical Shift $(\mathbf{p p m})$} \\
\cline { 2 - 5 } Proton No. & $\mathbf{( H L )}$ & $\mathbf{I}$ & $\mathbf{2}$ & $\mathbf{3}$ \\
\hline 4 & - & - & - & - \\
5 & $2.32 \mathrm{~s}$ & $2.24 \mathrm{~s}$ & $2.36 \mathrm{~s}$ & $2.29 \mathrm{~s}$ \\
6 & $7.48 \mathrm{~s}$ & $7.53 \mathrm{~s}$ & $7.48 \mathrm{~s}$ & $7.59 \mathrm{~s}$ \\
$-\mathrm{NH}$ & $5.07 \mathrm{~s}$ & - & - & - \\
\hline
\end{tabular}

${ }^{\mathrm{a}}$ Chemical shifts $(\delta)$ in ppm.

bultiplicity is given as s-singlet, d-doublet, coupling values are given in parenthesis<smiles>Cc1ccc2[nH]c(S)nc2c1</smiles>

(HL)

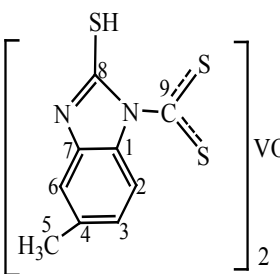

(1)

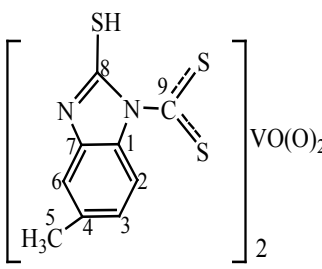

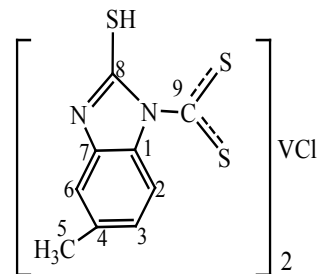

(3)

Scheme 2 NMR numbering scheme.

\section{c. ${ }^{13} \mathrm{C}-\mathrm{NMR}$ spectroscopy}

The characteristic resonance signals in the ${ }^{13} \mathrm{C}$ NMR spectra of synthesized vanadium complexes were recorded in duterated DMSO. The discrete ${ }^{13} \mathrm{C}$ signals for all the individual carbon atoms were identified and the data is given in Table 4.

Table $4{ }^{13} \mathrm{C}-\mathrm{NMR}$ spectral data ${ }^{\mathrm{a}}$ (ppm) of vanadium complexes

\begin{tabular}{llll}
\hline Carbon No. & I & $\mathbf{2}$ & 3 \\
\hline 1 & 134.26 & 134.35 & 134.29 \\
2 & 113.5 & 113.22 & 113.48 \\
3 & 122.75 & 122.73 & 122.69 \\
4 & 130.32 & 130.16 & 130.43 \\
5 & 23.41 & 23.62 & 23.45 \\
7 & 114.83 & 114.77 & 114.53 \\
8 & 134.42 & 134.25 & 134.63 \\
9 & 166.27 & 166.4 & 166.37 \\
\hline
\end{tabular}

${ }^{\text {a }}$ Chemical shifts $(\delta)$ in ppm.

\section{d. Antibacterial activity}

The antibacterial activity was checked against two bacterial strains by using disc diffusion method (Table 5). Rifampicine was used as a standard drug.

\section{e. Anti-biofilm activity}

The in vitro anti biofilm activity was checked against $S$. aureus Percentage biofilm inhibition of free ligand and its vanadium complexes is represented in Table 6.
Table 5 Antibacterial activity of ligand and vanadium complexes

\begin{tabular}{|c|c|c|}
\hline \multirow[t]{2}{*}{ Compound No. } & \multicolumn{2}{|c|}{ Zone of inhibition ( $\mathrm{mm}$ ) } \\
\hline & Escherichia coli & Bacillus subtilis \\
\hline $\mathrm{HL}$ & 10 & 10 \\
\hline I & 13 & 14 \\
\hline 2 & II & 12 \\
\hline 3 & II & 11 \\
\hline *Standard drug & 35 & 32 \\
\hline
\end{tabular}

* Rifampicine

Table 6 Biofilm inhibition potential of ligand and vanadium complexes

\begin{tabular}{ll}
\hline Compound No. & Biofilm inhibition (\%) \\
\hline HL & 3 \\
\hline & 18 \\
3 & 16 \\
$*$ Rifamacin & 14 \\
\hline
\end{tabular}

\section{*Standard drug}

\section{f. Cytotoxicity}

The cytotoxicity was checked against human red blood cells by hemolytic method. The results were compared with standard drug Triton X-100 (positive control) and PBS (negative control). The \% cytotoxicity is given in Table 7. 
Table 7 Hemolytic activity of ligand and vanadium complexes

\begin{tabular}{ll}
\hline Compound No. & Hemolytic activity (\%) \\
\hline $\mathrm{HL}$ & $0.31 \mathrm{I}$ \\
$\mathrm{I}$ & $\mathrm{I} 1.04$ \\
2 & 3.54 \\
3 & 2.27 \\
PBS & 0.64 \\
Triton-X-100 & 100 \\
\hline
\end{tabular}

\section{g. In vitro anticancer activity}

Anticancer activity of the vanadium complexes (1)-(3) was determined $\left(\mathrm{IC}_{50}\right.$ values in $\left.\mu \mathrm{M}\right)$ against two cancer cell lines as KBV200 and H460 MX2 by MTT assay. MTT is 3-(4,5-dimethyl2-thiazolyl)-2,5-diphenyl-2H-tetrazolium bromide. $\mathrm{IC}_{50}$ values for vanadium complexes are given in Table 8.

Table 8 Anticancer activity of vanadium complexes against KBV200 and H460 MX2 cancer cell lines

\begin{tabular}{lll}
\hline & \multicolumn{2}{l}{ Anticancer activity IC50 $(\mu \mathrm{M})$} \\
\cline { 2 - 3 } Compound No. & KBV200 & H460 MX2 \\
\hline I & 41.78 & 12.84 \\
2 & 39.59 & 2.55 \\
3 & $>50$ & $>50$ \\
\hline
\end{tabular}

\section{Discussion}

Elemental analysis $(\mathrm{C}, \mathrm{H}$ and $\mathrm{N})$ data of ligand and vanadium complexes (1)-(3) showed good agreement between found and calculated values. The characteristic IR peaks obtained for the ligand and vanadium complexes (1)-(3) were found in close agreement with the reported values given in the literature. ${ }^{35}$ The NH band of ligand disappeared and new bands for $v(\mathrm{C}-\mathrm{N}), \mathrm{v}(\mathrm{V}-\mathrm{S})$ and $v(\mathrm{CSS})$ were appeared in the range 1368-1371, 438-440 and 1169-1182 $\mathrm{cm}^{-1}$, respectively which confirms the complexation. ${ }^{36,37}$ The SH group did not take part in complexation. For complexes (1) and (2), new bands for $v(\mathrm{~V}=\mathrm{O})$ were also observed in the range $958-966 \mathrm{~cm}^{-1}$.

In the ${ }^{1} \mathrm{H}$ NMR spectra of studied complexes, all the protons present in the ligand and complexes have been identified in position and number with the protons calculated from incremental method. ${ }^{38}$ ${ }^{1} \mathrm{H}$ NMR data of free ligand shows a singlet of $-\mathrm{NH}$ group at $5.07 \mathrm{ppm}$. Signal of proton 2 appears as doublet in the range of 7.39-7.45ppm. The proton 3 shows a doublet in the range of 7.05-7.16ppm. The methyl protons appear as singlet at $2.32 \mathrm{ppm}$. Proton 6 shows a singlet at 7.48ppm. Proton 2 appears as doublet in the range of 7.34-7.73ppm. The proton 3 also shows a doublet in the range of 7.09-7.28ppm. Proton 5 of methyl group gives singlet in the range of 2.24-2.36 ppm. Proton 6 shows a singlet in the range of 7.48-7.59ppm.

In the vanadium complexes (1)-(3), the important chemical shift of the carbon attached with sulphur atoms $\left(\mathrm{CS}_{2}\right)$ was observed in the range 198.36-198.49 $\mathrm{ppm}$ that indicates the attachment of vanadium at this site. The high value of thione carbon chemical shift could be explained by an increase of pi-bond order in the whole $\mathrm{NCS}_{2}$ moiety. ${ }^{39}$ The zone of inhibition for standard drug was found to be 35 and $32 \mathrm{~mm}$ against $E$. coli and B. subtilis, respectively. Ligand (HL) and vanadium complexes (1)-(3) showed moderate antibacterial activity, while activity of complexes was found slightly greater than the ligand. Antibacterial activity for complex (1) was maximum than other complexes.

The ligand and vanadium complexes (1)-(3) showed moderate anti biofilm activity. Complex (1) showed highest value of biofilm inhibition activity (18\%), while complex (3) showed lowest activity (14\%). The activity of vanadium complexes was increased on complexation as reported earlier. ${ }^{40}$ According to chelation theory, the lipophilic character of metal complexes is increased on complexation that favours their permeation through bacterial membrane and blocks the metal binding sites. ${ }^{41}$

Ligand showed negligible cytotoxicity $(0.311 \%)$, while vanadium complexes (1)-(3) showed moderate values of hemolytic activity. Maximum cytotoxicity was found for complex (1) which was $11.04 \%$ while complex (3) showed minimum cytotoxicity. Vanadium complexes having $\mathrm{IC}_{50}$ values more than $50 \mu \mathrm{M}$ were considered inactive against anticancer activity. Vanadium complexes of 2-mercapto-5-methyl-benzimidazole ligand (HL) showed significant anticancer activity against H460 MX2 cell line. Complexes (1) and (2) were active against both cell lines but activity against H460 MX2 cells was greater and significant than KBV200. Complex (1) showed significant anticancer activity with $\mathrm{IC}_{50}$ value $12.84 \mu \mathrm{M}$ while complex (3) was found inactive against both cell lines. Complex (2) which is an oxo-peroxo-vanadium complex showed maximum activity $\left(\mathrm{IC}_{50} 2.55 \mu \mathrm{M}\right)$ against $\mathrm{H} 460 \mathrm{MX} 2$ cells and these results are also in accordance with the earlier reports. ${ }^{42}$

\section{Conclusion}

Vanadium complexes have been synthesized and characterized by different techniques. Elemental analysis data was found to be in good agreement with the calculated values. IR data suggested the bidentate nature of ligand. Multinuclear NMR data showed that complexation occurs through -NCSS moiety. The vanadium complexes and free ligand were checked for different biological activities such as antibacterial activity, cytotoxicity or hemolytic activity and in vitro anticancer activity. Ligand and synthesized vanadium complexes exhibited moderate antimicrobial and biofilm inhibition activity. The cytotoxicity study showed that $\%$ cytotoxicity of vanadium complexes is moderate but higher than free ligand. In vitro anticancer activity of synthesized vanadium complexes showed that complex (2) exhibited significant anticancer activity $\left(\mathrm{IC}_{50} 2.55 \mu \mathrm{M}\right)$ against $\mathrm{H} 460 \mathrm{MX} 2$ cell line.

\section{Acknowledgments}

None.

\section{Conflicts of interest}

The author declares that there are no conflicts of interest.

\section{Funding}

None.

\section{References}

1. Vanco J, Svajlenova O, Racianska E, et al. Antiradical activity of different copper (II) Schiff base complexes and their effect on alloxaninduced diabetes. J Trace Elem Med Biol. 2004;18:155. 
2. Obaleye JA, Adediji JF, Adebayo MA. Synthesis and biological activities on metal complexes of 2,5-diamino-1,3,4-thiadiazole derived from semicarbazide hydrochloride. Molecules. 2011;16(7):5861-5874.

3. Tai X, Yin X, Chen Q, et al. Synthesis of some transition metal complexes of a novel Schiff base ligand derived from 2,2'-bis(pmethoxyphenylamine) and salicylicaldehyde. Molecules. 2003;8(5):439-443.

4. Noblia P, Baran EJ, Otero L, et al. New vanadium (V) complexes with salicyl aldehyde semi carbazone derivatives: synthesis, characterization, and in vitro insulin-mimetic activity-crystal structure of [ $\mathrm{VO}_{2}$ (salicyl aldehyde semi carbazone)]. Eur J Inorg Chem. 2004;2:322-328.

5. Pattanayak P, Pratihar JL, Patra D, et al. Synthesis, structure and reactivity of azosalophen complexes of vanadium(IV): studies on cytotoxic properties, Dalton Transactions. 2009;1:6220-6230.

6. Messerschmidt,Wever R. X-ray structure of a vanadium-containing enzyme: chloroperoxidase from the fungus Curvulariainaequalis. USA: Proc Nat Acad Sci. 1996;93(1):392-396.

7. Crans DC, Tracey AS. The chemistry of vanadium in aqueous and nonaqueous solution, ACS Symp Ser. 1998;711(1):2-29.

8. Liasko R, Kabanos TA, Karkabounas S, et al. Beneficial effects of a vanadium complex with cysteine, administered at low doses on benzo $(\alpha)$ pyrene-inducedleiomyosarcomas in wistar rats. Anticancer Res. 1998;18(5):3609-3613.

9. Prasad P, Sasmal PK, Majumdar R, et al. Photocytotoxicity and near-IR light DNA cleavage activity of oxovanadium(IV) Schiff base complexes having phenanthroline bases. Inorg Chim Acta. 2010;363(12):27432751

10. Sasmal PK, Saha S, Majumdar R, et al. Photocytotoxic oxovanadium(IV) complexes showing light-induced DNA and protein cleavage activity. Inorg Chem. 2010;49(3):849-859.

11. Holder AA. Inorganic pharmaceuticals. Ann Rep Prog Chem A. 2011;107:359-378.

12. Sun Y, Joyce LE, Dickson NM, et al. DNA photo cleavage by an osmium(II) complex in the PDT window. Chem Commun 2010;46:6759-6761.

13. Dash SP, Pasayat S, Dash SHR, et al. Oxovanadium(V) complexes incorporating tridentate aroylhydrazoneoximes: synthesis, characterizations and antibacterial activity. Polyhedron. 2012;31(1):524529.

14. Leonard A, Gerber GB. Mutagenicity, carcinogenicity and teratogenicity of vanadium compounds. Mutat Res. 1994;317(1):81-88.

15. Dubyakand GR, Kleinzeller A. The insulin-mimetic effects of vanadate in isolated rat adipocytes. Dissociation from effects of vanadate as a $\left(\mathrm{Na}^{+}-\mathrm{K}^{+}\right)$ATPase inhibitor. J Biol Chem. 1980;255:5306-5312.

16. Cantley LC, Aisen P. The fate of cytoplasmic vanadium. Implication on (Na,K)-ATPase inhibition. J Biol Chem. 1979;254(6):1781-1784.

17. Willsky GR, Goldfine AB, Kostyniak PJ, et al. Crans, Effect of vanadium(IV) compounds in the treatment of diabetes: in vivo and in vitro studies with vanadyl sulfate and bis(maltolato)oxovandium(IV). $J$ Inorg Biochem. 2001;85(1):33-42.

18. Baran EJ. Oxovanadium (IV) and oxovanadium(V) complexes relevant to biological systems. J Inorg Biochem. 2000;80(1-2):1-10.

19. Nechay BR, Nanninga LB, Nechay PS. Vanadyl(IV) and vanadate(V) binding to selected endogenous phosphate, carboxyl, and amino ligands; calculations of cellular vanadium species distribution. Arch Biochem Biophys. 1986;251(1):128-138.
20. Pierce LM, Alessandrini F, Goldski JJ, et al. Vanadium-induced chemokine mRNA expression and pulmonary inflammation. Toxicol Appl Pharmacol. 1996;138(1):1-11.

21. Crans DC. Chemistry and insulin-like properties of vanadium(IV) and vanadium(V) compounds. J Inorg Biochem. 2000;80:123-131.

22. Wang J, Yuen VG, McNeill JH. Effects of vanadium on insulin sensitivity and appetite. Metabolism. 2001;50(6):667-673

23. Banerjee I, Pangule RC, Kane RS. Antifouling coatings: Recent developments in the design of surfaces that prevent fouling by proteins, bacteria and marine organisms. Adv Mater. 2011;23(6):690-718.

24. Wever R, Hemrika W. Handbook of Metalloproteins. In: Messerschmidt A, Huber R, Poulos T, et al, editors. Wiley. 2001;pp:1417.

25. Jabeen M, Ali S, Shahzadi S, et al. Synthesis, characterization, theoretica study and biological activities of oxovanadium(IV) complexes with 2-thiophene carboxylic acid hydrazide. J Photochem Photobiol B Biol. 2014; $136: 34-45$

26. Jabeen M, Ali S, Shahzadi S, et al. Synthesis, spectroscopy, theoretica study and biological activities of vanadium(IV) and vanadium(V) complexes with isonipecotic acid. Russ J Gen Chem. 2016;7:530.

27. Shahzadi S, Ali S, Parvez M, et al. Synthesis, spectroscopy and antimicrobial activity of vanadium(III) and vanadium(IV) complexes involving Schiff bases derived from tranexamic acid and $\mathrm{x}$-ray structure of zwitter ion of tranexamic acid. Russ J Inorg Chem. 2007;52:386-393.

28. Ashraf R, Shahzadi S, Ali S, et al. Difluorovanadium(IV) dicarboxylates: Coordination behaviour and biological activity. Russ J Coord Chem. 2007;33:576.

29. Muhammad N, Ali S, Shahzadi S. Oxovanadium(IV) complexes of nonsteroidal anti-inflammatory drugs (NSAIDs): Synthesis, spectroscopy, and antimicrobial activity, Russ J Coord Chem. 2008;34(6):456-460.

30. The Clinical Laboratory Standards Institute (CLSI); Performance standards for antimicrobial susceptibility testing. J Clin Microbiol. 2007; $45: 2758$

31. Huang G, Jiaxin J, et al. Antioxidant and antibacterial activity of the methanol extract of Artemisia anomala Moore S. African journal of technology. 2008;7(9):1335-1338.

32. Powell WA, Catranis CM, Maynard CA. Design of self-processing antimicrobial peptides for plant protection. Lett App Microbiol. 2000;31(2):163-168.

33. Kubota H, Senda S, Nomura N, et al. Biofilm formation by lactic acid bacteria and resistance to environmental stress. J Biosci Bioeng. 2008;106(4):381-386.

34. Mosmann T. Rapid colorimetric assay for cellular growth and survival: Application to proliferation and cytotoxicity assays. J Immunol Methods. 1983;65(1-2):55-63.

35. Pavia DL, Lampman GM, Kriz GS. Introduction to Spectroscopy. 3rd edn. Australia: Saunders College Publishing, Thomson Learning Inc. $2001 ; 167$.

36. Rehman W, Baloch MK, Badshah A, et al. Synthesis and characterization of biologically potent di-organotin(IV) complexes of mono-methyl glutarate. J Chin Chem Soc. 2005;52(2):231.

37. Rai A Sharma, R Sirohi. Synthesis, characterization and study of biological activity of oxovanadium(IV) complex of halogen substituted nitrophenylsalycylimine. VSRD-Tech Non-Tech J. 2011;2:604.

38. Kalinowski HO, Berger S, Brown S. 13C NMR Spectroscopy, Thieme Verlag, Stuttgart 1984. Germany: Online wiley. 1984;23(7):589. 
39. Nomura R, Fujii S, Takabe A, et al. Preparation of novel metal dithiocarbamate complexes containing u-OH group. Stabilization effect of the OH group on the HNCS2-Mt linkage. Polyhedron. 1989;8:1891.

40. Richards JJ, Huigens RW, Ballard TE, et al. Inhibition and dispersion of proteobacterial biofilms. Chem Commun. 2008;14:1698-1700.

41. Raman N, Kulandaisamy A, Jeyasubramanian K. Synthesis, structural characterization, redox and antimicrobial studies of Schiff base copper(II), nickel(II), cobalt(II), manganese(II), zinc(II) and oxovanadium(II) complexes derived from benzil and 2-aminobenzyl alcohol. Polish J Chem. 2002;76:1085.

42. Faure R, Vincent M, Dufour M, et al. Arrest of the G2/M transition of the cell cycle by protein tyrosine phosphatase inhibition: studies on a neuronal and aglial cell line. J Cell Biochem. 1995;59:389. 